\title{
THE CASE STUDY ON SOIL FAUNA DIVERSITY IN DIFFERENT ECOLOGICAL SYSTEM IN SHILIN NATIONAL PARK, YUNNAN, CHINA
}

PRIMER PREUČEVANJA RAZNOVRSTNOSTI TALNE FAVNE V RAZLIČNIH EKOLOŠKIH SESTAVIH V NARODNEM PARKU SHILIN (YUNNAN, KITAJSKA)

XIANG CHANGGUO $^{1} \&$ SONG LINHUA ${ }^{2} \&$ ZHANG PINGJIU ${ }^{1}$ $\&$ PAN GENXING $^{1}$

${ }^{1}$ Nanjing Agricultural University, Nanjing 210095, P.R. China

${ }^{2}$ Institute of Geography, Chinese Academy of Sciences, Beijing 100101, P.R. China 


\section{Xiang C. \& Song L. \& Zhang P. \& Pan G.: The case study on soil fauna diversity in different ecological system in Shilin national park, Yunnan, China}

A preliminary study of the distribution and diversity of soil fauna in a sequence of ecosystem degradation in the Shilin National Park, Yunnan, China has been made. The degraded ecologic system includes 5 types of vegetation cover: (1) natural bush; (2) human planted cypress forest; (3)natural grass; (4)secondary grass and (5) bared red earth. A quadrate of $1 \mathrm{~m} \times 1 \mathrm{~m}$ in each eco-tessera was sampled for soil fauna collection. The animals were obtained either by picking up or by heat-removing. The soil fauna were dominated by Acarina, Collembola, Nematode, Coleoptera, and Opistopora in these soils. However, Erchytraeidae, Araneida, Lepidoptera and Diptera were also common groups. The diversity index H turned to be less than 1.5, drastically decreasing with the vegetation degradation trend. In the karst soils, Parholaspidae was one of the most populous among the mites. The biomass of Trhypochthoniidae and Ologamasidae was very concentrated in the natural bush ecosystem, showing high sensitivity of mites to vegetation degradation. The biomass ratio of Acarina to Collembola in the studied soils ranged from 0.70 to 1.50 , which was in great discrepancy to the results reported of the natural soils at similar latitude. The small soil fauna biomass and less diversity indicated that the studied soil was in a state of deterioration of soil fauna habitats and, in turn, the soil ecosystem health. The results also evidenced that the soil fauna in the karst soil was definitely vulnerable as regarded to the sustainable development of the Shilin Park.

Keywords: Stone Forest; karst soils; fauna diversity; vegetation cover; ecosystem degradation.

\section{Izvleček}

UDC: 574:551.44(510)

\section{Xiang C. \& Song L.\& Zhang P. \& Pan G.: Primer preučevanja raznovrstnosti talne favne v različnih ekoloških sestavih v narodnem parku Shilin (Yunnan, Kitajska)}

Predhodno sta bili preučevani razporeditev in raznovrstnost talne favne $\mathrm{v}$ vrsti degradiranih ekosistemov $\mathrm{v}$ narodnem parku Shilin. Ti ekosistemi vključujejo pet tipov rastlinskega pokrova: 1. naravno grmišče, 2. umetno nasajen cipresov gozd, 3. naravni travnik, 4. drugotni travnik, 5. golo rdečo prst. Na vsakem izmed njih je bila talna favna nabrana s kvadrata velikosti $1 \mathrm{krat} 1 \mathrm{~m}$. •ivali so bile nabrane ročno ali pa izločene s pomočjo segrevanja. $\mathrm{V}$ talni favni so prevladovale acarina, collembola, nematoda, coleoptera in opistopora. Toda razmeroma pogoste so bile tudi skupine enchytraeidae, araneida, lepidoptera in diptera. Indeks raznovrstnosti $H$ je manjši od 1,5 in se močno zni uje vzporedno z degradacijo rastlinstva. $V$ kraških prsteh so med najpogostejšimi parholaspidae. Biomasa trhypochthoniidae in ologamasidae je najbolj zgoščena $\mathrm{v}$ naravnem grmišču in ka•e veliko občutljivost teh skupin na degradacijo rastlinstva. Razmerje biomase acarina v primerjavi s collembola je v razponu 0.7 do 1.5 , kar je veliko odstopanje od podatkov za naravne prsti podobnih geografskih širin, znanih iz literature. Majhna biomasa talne favne in manjša raznovrstnost ka•eta, da se habitati v preučevanih prsteh slabšajo in se torej slabša tudi zdravje celega ekosistema. Izsledki tudi ka•ejo na ranljivost talne favne v prsteh z vidika sonaravnega razvoja parka Shilin.

Ključne besede: kraška prst, biodiverziteta, rastlinski pokrov, degradacija ekosistema, Shilin, Yunnan, Kitajska. 
The relationship between soil fauna diversity and ecological system has been broadly noted and researched by many scientists ( Griffiths et al., 2001; Filip, 2002; Mikola et al., 2002) . Soil fauna are the main consumers and decomposers of organic matters in the soil. Lal (1988) recognized that the soil fauna affected the soil property in the tropical ecosystem. Five years later the variations of the soil fauna groups in the ecosystem degradation and recovery processes were clearly understood (Curry \& Good, 1992). Bauble et al. (1997) pointed out that soil large animals could be the biomarker of the soil environmental change. In recent years more researchers show that the number and diversity of the earthworm groups can be used as the biomarker of the ecosystem health, which responds immediately to the soil environmental pollution and ecosystem degradations. The studies showed that carbon transportation produced by the organisms was the basic characteristics in the epi-karst zone (Pan \& Cao, 1999; Cao \& Yuan \& Pan, 2001), so the living and activity of soil animals is very important for the form and transformation of the soil organic matter. The fragile and stability of the karst ecosystem can be explained by the function of the soil fauna diversity as well as the soil carbon transformation effect on the karstification. The karst areas are the main fragile ecology system area, the karst ecology system in Southwest China has been seriously degraded and the environment is getting worse and worse; it even appeared rocky desertification ( Song, 1999; Yuan, 2000; ). Many researches have focused on the soil microbial biomass and its dynamics in the karst areas. But there is little knowledge about the structure and change of the soil animal group in the karst area. This paper deals with the relationship between the soil fauna diversity and karst ecosystem and the soil fauna as the index of the karst ecosystem changes in the Shilin National Park.

\section{BRIEF INTRODUCTION OF STUDIED AREA AND RESEARCH METHODS}

The studied area was chosen in the Naigu Scenic spot of Shilin National Park at the altitude of $1820 \mathrm{~m}$. It belongs to the subtropical monsoon climate with a mean annual precipitation of $970 \mathrm{~mm}$ and temperature 15.6!. The shilin (stone forest) karst landscape develops in the Lower Permian limestone. The shilin landscape has been created by subsoil solution and subaerial solution in the long term (Liang \& Song, 2000). The natural vegetation in the area is bush; the steady plant community is fitted to the ecosystem with much stone and little soil. Since the scenic spot was opened for visitors in 1991 the original vegetation was partly reformed including replanting of some species of tree and grass, and some farmland has been retired. The soil is mainly calcareous eluvial soil resulted from limestone weathering, which suffered unfair erosion in the ecosystem degradation.

There are 5 representative ecosystems in Naigu Spot according to the vegetation:

1. Natural bush with $120 \sim 150 \mathrm{~cm}$ high and area covered nearly $100 \%$;

2. Cypress with 20 years old, $5 \sim 6 \mathrm{~m}$ high, $2.5 \mathrm{~m}$ row spacing, $1.5 \mathrm{~m}$ tree spacing, covered $100 \%$.

3. Natural grass with much couch grass, $80 \sim 100 \mathrm{~cm}$ high, $70 \sim 100 \%$ covered.

4. Secondary grass with sparse couch, $60 \sim 80 \mathrm{~cm}$ high, less than $70 \%$ covered.

5. Bared red earth with sparse couch.

The standard sampled plot with acreage of $1 \mathrm{~m} \times 1 \mathrm{~m}$ was established randomly in each ecosystem. In every plot the soil was sampled from $0 \sim 10 \mathrm{~cm}, 10 \sim 20 \mathrm{~cm}, 20 \sim 30 \mathrm{~cm}$ and $30 \sim 40 \mathrm{~cm}$ below soil surface. The macroscopic soil fauna were collected by hand and identified visually; little or micro soil fauna were gathered by the method of Tullgren (dry funnel) and Baormaun (wet funnel) and identified by microscope. The inactive larva and protozoan were not determined by these methods. The taxonomy and statistics of the gathered soil fauna were mainly dependent on the methods brought forward by Yin et al. (1992, 2000). 


\section{RESULTS AND DISCUSSION}

\section{The composition and number of the soil fauna community of in the Stone Forest}

935 samples of animals were obtained. They belong to the 28 species: Arthropoda such as Insecta, Arachnida, Chilopoda, Malacostraca, Diplopoda, Symplyla; Annelida, such as Oligochaeta, Hiradinea; Nemata, such as Nematoda; Rotatoria, such as Rotatoria; Turbellaria, such as Turbellaria (Table 1). The dominant communities of the soil fauna are Acarina, Collembola, Nematoda, Coleoptera and Opistopora,

Table 1. The species and amounts of the soil fauna in the various ecosystem in the Forest Stone Park

\begin{tabular}{|c|c|c|c|c|c|c|c|}
\hline Species & natural bush & cypress & high grass & $\begin{array}{r}\text { scarce } \\
\text { grass }\end{array}$ & $\begin{array}{l}\text { bared } \\
\text { soil }\end{array}$ & $\begin{array}{c}\text { total } \\
\text { individuals }\end{array}$ & $\begin{array}{l}\text { percentage } \\
\text { of total } \\
\text { samples }(\%)\end{array}$ \\
\hline Acarina & 117 & 57 & 24 & 6 & 6 & 210 & 22.46 \\
\hline Collembola & 58 & 40 & 27 & 9 & 4 & 138 & 14.76 \\
\hline Nematoda & 35 & 38 & 25 & 8 & 2 & 108 & 11.55 \\
\hline Enchytraeidae & 6 & 4 & 1 & 1 & 0 & 12 & 1.28 \\
\hline Opistopora & 140 & 26 & 14 & 3 & 0 & 183 & 19.57 \\
\hline Hymenoptera & 9 & 2 & 9 & 5 & 1 & 26 & 2.78 \\
\hline Coleoptera & 21 & 79 & 8 & 2 & 5 & 115 & 12.30 \\
\hline Araneida & 9 & 4 & 23 & 0 & 1 & 37 & 3.96 \\
\hline Lepidoptera & 8 & 6 & 1 & 3 & 0 & 18 & 1.93 \\
\hline Diptera & 7 & 4 & 5 & 1 & 0 & 17 & 1.82 \\
\hline Diplura & 3 & 1 & 4 & 0 & 0 & 8 & 0.86 \\
\hline Symphyla & 3 & 0 & 3 & 2 & 0 & 8 & 0.86 \\
\hline Orthoptera & 2 & 0 & 4 & 0 & 0 & 6 & 0.64 \\
\hline Scolopendromorpha & 2 & 1 & 3 & 0 & 0 & 6 & 0.64 \\
\hline Geophilomorpha & 2 & 0 & 1 & 1 & 0 & 4 & 0.43 \\
\hline Protura & 3 & 1 & 0 & 0 & 0 & 4 & 0.43 \\
\hline Isoptera & 1 & 0 & 3 & 0 & 0 & 4 & 0.43 \\
\hline Isopoda & 4 & 0 & 0 & 0 & 0 & 4 & 0.43 \\
\hline Rotatoria & 0 & 3 & 2 & 1 & 0 & 6 & 0.64 \\
\hline Hemiptera & 5 & 0 & 0 & 0 & 0 & 5 & 0.53 \\
\hline Diplopoda & 3 & 1 & 0 & 0 & 0 & 4 & 0.43 \\
\hline Thysanoptera & 0 & 2 & 0 & 0 & 0 & 2 & 0.21 \\
\hline Turbellaria & 1 & 1 & 0 & 0 & 0 & 2 & 0.21 \\
\hline Palpigradi & 0 & 0 & 1 & 0 & 0 & 1 & 0.11 \\
\hline Blattaria & 0 & 0 & 2 & 0 & 0 & 2 & 0.21 \\
\hline Dermaptera & 2 & 0 & 0 & 0 & 0 & 2 & 0.21 \\
\hline Opiliones & 1 & 0 & 0 & 0 & 0 & 1 & 0.11 \\
\hline Pseudoscorpionida & 1 & 0 & 0 & 0 & 0 & 1 & 0.11 \\
\hline Hirudinea & 1 & 0 & 0 & 0 & 0 & 1 & 0.11 \\
\hline $\begin{array}{l}\text { Biomass } \\
\text { (individuals } / \mathrm{m}^{2} \text { ) }\end{array}$ & 444 & 270 & 160 & 42 & 19 & 935 & 100.00 \\
\hline \multicolumn{2}{|c|}{ Percentage of total samples } & 47.49 & 28.88 & 17.11 & 4.49 & 2.03 & 100.00 \\
\hline
\end{tabular}


the common community includes Traeidae, Hymenoptera, Araneae, Lepidoptera and Diptere, others are scarce community. The number of the soil fauna is similar to the well protected forest at the same latitude, but there is difference among the number of dominant community of the sampled soil. The biomass of the forest soil fauna at the same latitude is higher with the individuals density of 1000 per square meter. The large scale soil fauna decreased obviously when the individual density is below 200 per square meter, which means the biomass of soil fauna tends to decrease because of the vegetation degradation and human disturbance.

\section{Effect of various vegetation and soil depth on structure and number of soil fauna}

There are significant effects of various vegetation on the structure and number of soil fauna in the Shilin area. The individual number of the soil fauna in the natural bush amounts $47.6 \%$ of the total number and $89.3 \%$ of all species in the studied area. While the individual number and species in the soil without vegetation covers are $2.1 \%$ of the totals. The biomass of soil fauna is strongly affected by the vegetation degradation. The dominant communities of soil fauna changes with the variation of vegetation. The dominant communities are Acarina and Opistopora in the natural bush soil, but are Collembola and Nematoda in the soil under the planted cypress. The gross biomass of soil fauna decreased sharply with the destruction of vegetation as well as with the soil depth. There are abundant soil fauna at the $40 \mathrm{~cm}$ depth in the soil of natural bush, however only few soil fauna at the $40 \mathrm{~cm}$ depth in the cypress and grass soil. Wang et al. (1999) described that the gross soil fauna biomass and their distribution in the different depth are relation to the depth of A layer and the content of organic materials (OMC) in the ecosystem degradation despite the fauna epi-accumulative is very clear in the forest of Hengshan Mountain. The A layer is $20 \mathrm{~cm}$ down in the soil of natural bush but only about $10 \mathrm{~cm}$ in the cypress or grassland soil. The A layer with little soil fauna number and community is very thin in the bared red soil. The OMC in the A layers are $44.4 \mathrm{~g} / \mathrm{kg}, 25.0 \mathrm{~g} / \mathrm{kg}, 20.97 \mathrm{~g} / \mathrm{kg}$ and $19.48 / \mathrm{kg}$ in the natural bush, secondary cypress, natural grass and secondary grass, respectively. There is a logarithmic positive correlation between the density of the gross soil fauna and $\mathrm{OMC}$ in the A layer.

The decrease of soil fauna biomass under the various vegetation conditions is caused by the degradation of the vegetation resulting in the reduction of organic matter inputting into the soil. In this case, the smaller food and nutrients supply restrict the soil fauna development.

Table 2. Distribution of the soil fauna in soil depth under different vegetation

\begin{tabular}{lcccccccc}
\hline & \multicolumn{3}{c}{ total individuals } & \multicolumn{5}{c}{ total communities } \\
\hline Soil depth $(\mathrm{cm})$ & $0-10$ & $10-20$ & $20-30$ & $30-40$ & $0-10$ & $10-20$ & $20-30$ & $30-40$ \\
\hline natural bush & 307 & 109 & 19 & 11 & 16 & 16 & 3 & 3 \\
secondary cypress & 184 & 74 & 9 & 1 & 15 & 4 & 1 & 1 \\
Original grass & 107 & 3 & 10 & 1 & 15 & 4 & 3 & 1 \\
Secondary grass & 25 & 16 & 2 & 0 & 10 & 5 & 1 & 0 \\
Bared soil & 15 & 5 & 0 & 0 & 6 & 2 & 0 & 0 \\
\hline
\end{tabular}

\section{The distribution of the Acarina and Collembola}

Acarina and Collembola are the common dominant community. As Acarina is very sensitive to delicate environmental change, it is often employed to indicate the evolution of the environment (Yin \& Zhang et al, 2000; Yin \& Yang 1992). 
The ratio values of the individual numbers of the Acarina and Collembola are decreased with the increase of heat energy. In the ecosystem of natural forest to the south of Changjiang River, the ratio values are less than 0.55 . The results show that most Acarina cannot live well and even disappear in the condition of vegetation degradation. The ratio values under the different vegetation covers are between 0.3 and 1.5 (Table 3 ).

Table 3. The density of the acarina and collembola in the sampled soil (individuals $/ \mathrm{m}^{2}$ )

\begin{tabular}{lccccc}
\hline Species & natural & cypress & high grass & sparse grass & bared earth \\
\hline Trhypochthoniidae & 20 & 2 & not detected & not detected & 2 \\
Bdellidae & 20 & 14 & not detected & not detected & not detected \\
Gustaviidae & 16 & 6 & 2 & no detected & no detected \\
Ologamasidae & 7 & not detected & not detected & not detected & not detected \\
Veigaiidae & 11 & not detected & not detected & 2 & not detected \\
Stigamaeidae & 14 & 10 & 5 & not detected & not detected \\
Phthiracaridae & 15 & 12 & not detected & not detected & not detected \\
Acaridae & 3 & 12 & no detected & no detected & 2 \\
Lohmanniidae & not detected & not detected & 13 & 2 & not detected \\
Parholaspidae & 11 & 1 & 4 & 2 & 2 \\
Total & 107 & 57 & 24 & 6 & 6 \\
Isotoma & 30 & 17 & 12 & not detected & not detected \\
Onychiurus & 15 & not detected & 2 & 5 & 2 \\
Cryptopygus & 13 & 11 & not detected & not detected & 1 \\
Sphaeridia & not detected & 12 & not detected & 1 & 1 \\
Hypogastrura & not detected & not detected & 13 & 3 & not detected \\
total & 68 & 40 & 27 & 9 & 4 \\
Acarina/Collembola & 1.6 & 1.4 & 0.9 & 0.7 & 1.5 \\
\hline
\end{tabular}

Table 3 shows Acarina, Trhyprochthonisdae and Ologamasidae are the most sensitive to the ecosystem changes, Painolaspidae is much adaptive to various vegetation. Onychiurus in the Collembola cannot live in the soil covered by cypress.

\section{The biodiversity of the soil fauna}

The soil fauna abundance index (D), diversity index $(\mathrm{H})$ and uniformity $(\mathrm{J})$ can be calculated by the following equation:

$$
\mathrm{D}=(\mathrm{s}-1) / \ln \mathrm{N}
$$

Here $\mathrm{s}$ is the gross number of community and $\mathrm{N}$ is the gross number of individuals.

$$
\mathrm{H}=-\sum_{I=1}^{s} P i \ln P i
$$

In which $P i=N i / N$, where $N$ is the gross quantity of individuals and $N i$ is the amount of the individuals of $i$ community. 


$$
\mathrm{J}=\frac{H}{H \max }
$$

Here $H$ is the diversity index and Hmax is the maxium biodiversity index.

The results are showed in Table 4 .

Table 4. Change of soil fauna diversity under the various vegetation

\begin{tabular}{lccccc}
\hline index & natural bush & cypress & tall grass & sparse grass & bared earth \\
\hline total communities & 25 & 16 & 19 & 12 & 6 \\
total individuals & 444 & 270 & 160 & 42 & 19 \\
abundance (D) & 3.94 & 2.68 & 3.55 & 2.94 & 1.70 \\
biodiversity (H) & 1.34 & 0.93 & 0.72 & 0.24 & 0.11 \\
uniformity (J) & 0.212 & 0.225 & 0.135 & 0.188 & 0.290 \\
\hline
\end{tabular}

The study results gave all the community amounts under the degradated vegetation as less than 20, except that under natural bush, which accords with the results of the sub-tropical ecosystem (Yin \& Yang et al, 1992; Liao \& Li \& Huang 1997). The soil faunal biodiversity index H is 1.34 under natural bush but 0.11 under bared red earth. Under natural bush the indexes of abundance, diversity and uniformity are higher than those under other vegetation, but the uniformity under bared red earth is obviously higher than that under other vegetation, that might be caused by the structure of soil fauna rather simplified. These results showed that under the natural vegetation the abundance and diversity of the soil fauna is higher and that under the seriously degraded bared earth is lower, but the uniformity higher with the vulnerable soil fauna ecosystem.

\section{CONCLUSION}

The Acarina, Collembola, Nematoda, Coleoptera and Opistopora are the dominant communities, Onchytraeidae, Opiliones lepido, Diptera are the normal community; others are the scarce community.

Painolaspidae is adaptive in any environmental vegetation. Gross biomass amounts of community and the index of biodiversity in the soil of natural bush are much higher than those in the soil of other degraded vegetation, which show that the natural bush is the ecological screen protecting the soil fauna from deterioration. The gross biomass of soil fauna is less than those in the forest of the same latitude and the diversity of soil fauna decreased sharply in the various degraded vegetation, which indicate the deterioration of the soil ecosystem.

\section{REFERENCES AND BIBLIOGRAPHY}

Bauble B M, Schmidt O.1997: Can the abundance or activity of soil macrofauna be used to indicate the biological health of soils? In: Panthers C(ed.). Biological Indicators of Soil Health. CAB International, 265-295

Cao J.H., Yuan D.X., Pan G.X. 2001: Preliminary study on biological action in karst dynamic system. Earth Science Frontiers, 8 (1):203-209 
Curry J. P., Good. J. A., 1992: Soil fauna degradation and restoration. In: Lal, R. and Stewart, B. A. (ed) Soil Restoration. In: Lal R, Stewart B A(eds.), Advances in Soil Science, Vol 17, Michigan: Springer-Verlag, 171-203

Filip Z.. International Approach to Assessing Soil Quality by Ecologically-related Biological Parameters. Agriculture, Ecosystems and Environment, 2002: 88: 169-174.

Griffiths B.S., Ritz K., Wheatley R., Kuan H.L., Boag B., Christensen S., Ekelund F., Sørensen S.J., Muller S., Bloem J., 2001: An Examination of the Biodiversity-Ecosystem Function Relationship in Arable Soil Microbial Communities. Soil Biology \& Biochemistry, 33: 1713-1722.

Lal R., 1988: Effects of macrofauna on soil properties in tropical ecosystems. Agric. Ecosystems Environ, 24(1-3):101-116

Liang Fuyuan, Song Linhua, Wang Fuchang, Zheng Bingyuan, Zhang Liping, 2000: The case stuffy of subsoil solution features and soil $\mathrm{CO}_{2}$ concentration in Stone Forest Region, Lunan, Yunnan, China. Carsologica Sinica, 19 (2): 180-187.

Liao C.H., Li J.X., Huang H.T., 1997: Soil animal community diversity in the forest of southern subtropical region, China. Acta Ecologica Sinica, 17 (5): 549-555

Mikola, M., Basrdgett, R. D., Hedlund K., 2002. Biodiversity, ecosystem functioning and soil decomposer food webs. (not published, oral communication)

Pan G. X., Cao J. H., 1999: Karstification in epikarst zone: the earth surface ecosystem process taking soil as a medium- case of the Yaji karst experiment site, Guilin. Carsologica Sinica, 18 (4): $287-296$

Research Group of Stone Forest, 1997: Study of Karst of Stone Forest in Lunan County, Yunnan, China[M] Science and Technology Press, Kunming, Yunnan

Scott-Fordsmand J. J., Weeks J. M. Biomarkers in Earthworms, 2000: Review of Environmental Contamination and Toxicology, 165:117-159

Song Linhua, Sustainable development of agriculture in karst areas, South China, 1999: International Journal of Speleology. 28 B (1/4): 139-148.

Spurgeon D. J., Hopkin S. P. Seasonal variation in the abundance, biomass and biodiversity in soils contaminated with metal emissions from a primary smelting works, 1999: Journal of Applied Ecology, 36: 173-183

Sumner M. E. (Editor-in-chief). Handbook of Soil Science, 2000: Section C. Soil Biology and Biochemistry. Boca Raton- London- New York-Washington D C, C45-C85

Wang Z. Z., Zhang Y. M. The community structure of soil animals in forest of Hengshan Mountain. Acta Geographica Sinica, 1999,6(2):205-213

Yin W. Y., Yang F. C., Wang Z. Z. et al., 1992: Subtropical Soil Animals of China. Science Press, Beijing, China, 225-331

Yin W. Y., Zhang R. Z., Wang S.Z., et al., 2000: Soil Animals of China. Science Press, Beijing, China, 81-85

Yuan Daoxian. Rock desertification in the subtropical karst of South China, 2000: World Correlation of Karst Ecosystem Newsletter (Project 448), 41-52

This research project was financed from the National Natural Science Foundation (No. 499972087 and 90202017) and Shilin research Foundation. 